\title{
Archaeometric study of Roman tesserae from Salamanca (Spain). Archaeology and geochemical analysis
}

\author{
Verónica Pérez de Dios ${ }^{\mathrm{a}}, \mathrm{M}^{\mathrm{a}}$ de los Reyes de Soto García ${ }^{\mathrm{b} *}$, \\ Isabel de Soto García ${ }^{\mathrm{c}}$, Rosario García Giménez ${ }^{\mathrm{d}}$ \\ ${ }^{a}$ Department of Prehistory, Ancient History and Archaeology, Faculty of Geography and History, University of Salamanca, Calle de Serranos, 37008 \\ Salamanca, Spain \\ ${ }^{b}$ Institute of Archaeology of Merida (IAM)-Spanish National Research Council- Junta de Extremadura- Plaza de España,15, 06800 Mérida (Badajoz), Spain \\ 'Department of Sciences, School of Agricultural Engineering, Public University of Navarre, Los Olivos Building, Campus Arrosadia, 31006 Pamplona, Spain \\ ${ }^{d}$ Departament of Geology and Geochemistry. Faculty of Science. Autonomous University of Madrid, Campus de Campoblanco C, Francisco Tomás y \\ Valiente 7, Módulo 06, 28049 Madrid, Spain
}

\section{ARTICLE INFO}

Article history

Received: $17^{\text {th }}$ February 2017

Accepted: $4^{\text {th }}$ June 2018

DOI: http://dx.doi.org/ 10.24916/iansa.2018.1.3

\section{Keywords:}

tesserae

Roman villa

Salamanca

geo-chemical analysis

\section{A B S TRACT}

In this study an analysis was made of 37 samples of tesserae of different shades and colours from Roman archaeological sites in the province of Salamanca (Spain), where pavements of opus tessellatum have been located. The tesserae were characterized by Mass Inductively Coupled Plasma Mass Spectrometry (ICP-MS), X-Ray Diffraction (XRD) and Spectrometry, in order to determine their origin, composition and technique of manufacture. Results could reveal to us the local production of certain tesserae and the existence of a commercial network through the Via de la Plata and its main roads in the Iberian Peninsula.

\section{Introduction}

The taste for decorative flooring is not a particular tradition of the Roman Empire: in fact we need to go back in time until Uruk's period, at the Mesopotamian culture. The people of Uruk were the first culture to beautify walls and columns with geometric mosaic-based terracotta cones of different shades, whose decorative function evinced the extravagance of the place and its owner (Rossi, 1971, pp. 6-34; Bertelli, 1988, pp. 9-44; Fiorentini, 2001, pp. 17-39; Palomar, 2011, p. 54). The musivaria technique has not only become clear in the archaeological remains but also in classical written sources - Vitruvius and Pliny and the Edict of Diocletian itself. Therefore, mosaics are one of the decorative elements used by the Romans to decorate their buildings. It consists of small pieces, called tesserae, whose combination following a model or set pattern were used to decorate pavement. The tesserae are usually cubic in shape and made of different

*Corresponding author. E-mail: reyesdesoto@gmail.com materials such as marble, ceramic, stone or glass. The different types of colours and sizes allow them to create patterns - from the most simple to more elaborate - all of it can be observed for example in the large villas of the Roman Empire, such as the Roman villa of Casale in Sicily (Italy) or the Roman villa of Noheda in Cuenca (Spain).

Traditionally in Spain, mosaic pavements have been studied from an iconographic point of view. However, there are only a few examples of studies of the characterization of tesserae mosaics (Palomar, 2011; Flores et al., 2011; de Soto et al., 2014). The last few years, the rise of multidisciplinary analysis has greatly increased interest in the realization of archaeometric studies, although these types of analysis were not very abundant in Spanish science and not implemented widely until the 1980s (Garcia, Olaetxea, 1992, p. 266). These studies, apart from their purely descriptive interest, were intended to identify the petrography, disclose manufacturing techniques of the tesserae, analyse the sources of supply of materials to thus make inferences about trade relations, and alleviate the problems of conservation of pavements 
(Butzer, 1989, p. 153; James, 2006). In this sense, the main objective of our work is to analyse the petrographic origin of the tesserae from the different mosaics known so far in the province of Salamanca, to infer some historical conclusions, and corroborate the existence of certain trade routes linked to mosaic workshops.

In this article we will study 37 tesserae samples of different colours from seven Roman sites in Salamanca (Spain): Los Villares -LV- (Fresno Alhándiga); Alquería de Azán -AZand Aldearrica -AL- (Miranda de Azán); San Julián de la Valmuza -SJ- (San Julián de la Valmuza); San Morales -SM- (Aceña de la Fuente); La Vega -LVE- (Villoruela); and Saelices -SA- (Saelices el Chico).

The aim of this work is to study the origin, composition and the technique of manufacture of the tesserae in order to determine local production or the existence of a commercial route connecting mosaic workshops. The samples were analyzed using geochemical techniques such as Inductively Coupled Plasma Mass Spectrometry (ICP- MS) and X-Ray Diffraction (XRD). Finally, the results were studied using statistical techniques.

\section{Geographic context}

The Salamanca region is situated in central-western Spain. It is bordered to the north by Zamora and Valladolid, to the east by Ávila, to the south by Caceres and to the west by Portugal (Figure 1). The studied area is geologically situated within the Central Iberian Zone. It has an average altitude around $800 \mathrm{~m}$ but there are large variations throughout the province, upward to 2,428 $\mathrm{m}$ in the Sierra de Béjar and down to $116 \mathrm{~m}$ in the valley of the Salto de Saucelle. From a geographical point of view, the province of Salamanca is divided into three different areas (Lucena-Conde, García, 1976):

The mountains: located in the south of the region. The altitude ranges between 1,000-2,500 m. Granites, quartzites and slates are present in this area. The soils are acid and siliceous-humid soils are abundant in the mountain areas.

The high plateau: located in the centre of the region and in the $\mathrm{W}$ and NW. Slates and granites are abundant in this area and thus soils are siliceous.

The Duero Basin: materials are sedimentary rocks such as conglomerates, sands, clays and limestone from the Tertiary era. The most productive soils of the Salamanca region are located in this area.

Alongside these geographical features, the abundance of waterways and the likely environmental conditions became the central plateau in a favourable area for the proliferation of new settlements in Roman times.

\section{Antecedents: Roman villae with mosaic pavements of the province of Salamanca (Spain)}

Although the urban development of the modern city of Salamanca began in the second half of the first century AD, the evolution of the Roman rural settlement is unknown. However, we have one important archaeological fact, the creation of the Silver Way, a reference point next to the famous mansios and other rural settlements of various types with productive and residential functions (Roldán, 1971; Martín, Benet, Macarro, 1991; Salinas, 1998; Ariño, Díaz, 1999, pp. 153-192; Menéndez, 2000-2001; Chavarria, 2006, pp. 18-25). A recent archaeological survey carried out in the province has corroborated the existence of numerous agricultural and livestock establishments of the second order, and obviously larger settlements that may be classified as villae, thanks to the ostentatious archaeological material recovered (Pérez, 2014; de Soto, 2015). Although in the Provincial Archaeological Inventory, most deposits of Roman chronology are identified as villae, it is necessary to compare information based on ancient archaeological surveys. In order to determine which settlements could safely be ascribed to this category, we have analysed the databases in which it is recorded all the archaeological material from the Roman sites of Salamanca province. The aim was to locate certain ostentatious materials, such as mosaic pavements, in order to corroborate the existence of villae. The search results allowed us to catalogue seven sites with mosaics floors, six of them located in the valley of the Tormes River, and the last one placed on the riverside of the Agueda.

\subsection{Mosaic pavements in the West: the village of Saelices} Located in the municipality of Saelices el Chico and invading most of the current town, crops and column bases of Roman chronology were discovered when the foundation of a house was made in the 1980s. Subsequent archaeological excavation of the site brought to light several housing structures in which appeared a mosaic of about $13 \mathrm{~m}^{2}$ with a geometric decoration that highlights Solomon's knots that form three rows of square lattices of $48.5 \times 48.5 \mathrm{~cm}$ in which various geometric motives, vegetable and chequered patterns are inserted. The pavement, very similar to the north gallery of the peristyle of the Roman villa of La Olmeda, used to be part of a corridor of the urban part of the villa (Chamoso, Hernandez, 1997; Chamoso, 2007).

\subsection{Roman villas with mosaic pavements in the valley of the Tormes River}

In the municipality of Miranda de Azan, two settlements have been located with mosaic pavements: Alquería de Azán, the most relevant of these, and Aldearrica. The site of Alquería de Azán was first recorded by Father César Morán, who documented slate graves and archaeological remains attributable to Roman times (Morán, 2000, p. 58). Later, in the 1980s, Benet and Santonja documented white, black and red tiles of a small size that corroborated the existence of at least one mosaic floor (Benet, Santonja, 1990, p. 286). Meanwhile, at the site of Aldearrica, cited by Morán and Maluquer, a scattering of Roman materials, including various tesserae, were found (Morán, 2000; Maluquer, 1956).

North of Miranda de Azán, in the municipality of Doñinos, the first figurative mosaic of the province of Salamanca was 
Figure 1. Map with a geographical position of the analysed sites 1 - Los Villares (Fresno Alhándiga); 2, 3 - Alquería de Azán and Aldearrica (Miranda de Azán); 4 - San Julián de la Valmuza (San Julián de la Valmuza); 5 - San Morales (Aceña de la Fuente); 6 - La Vega (Villoruela) and 7 - Saelices (Saelices el Chico).

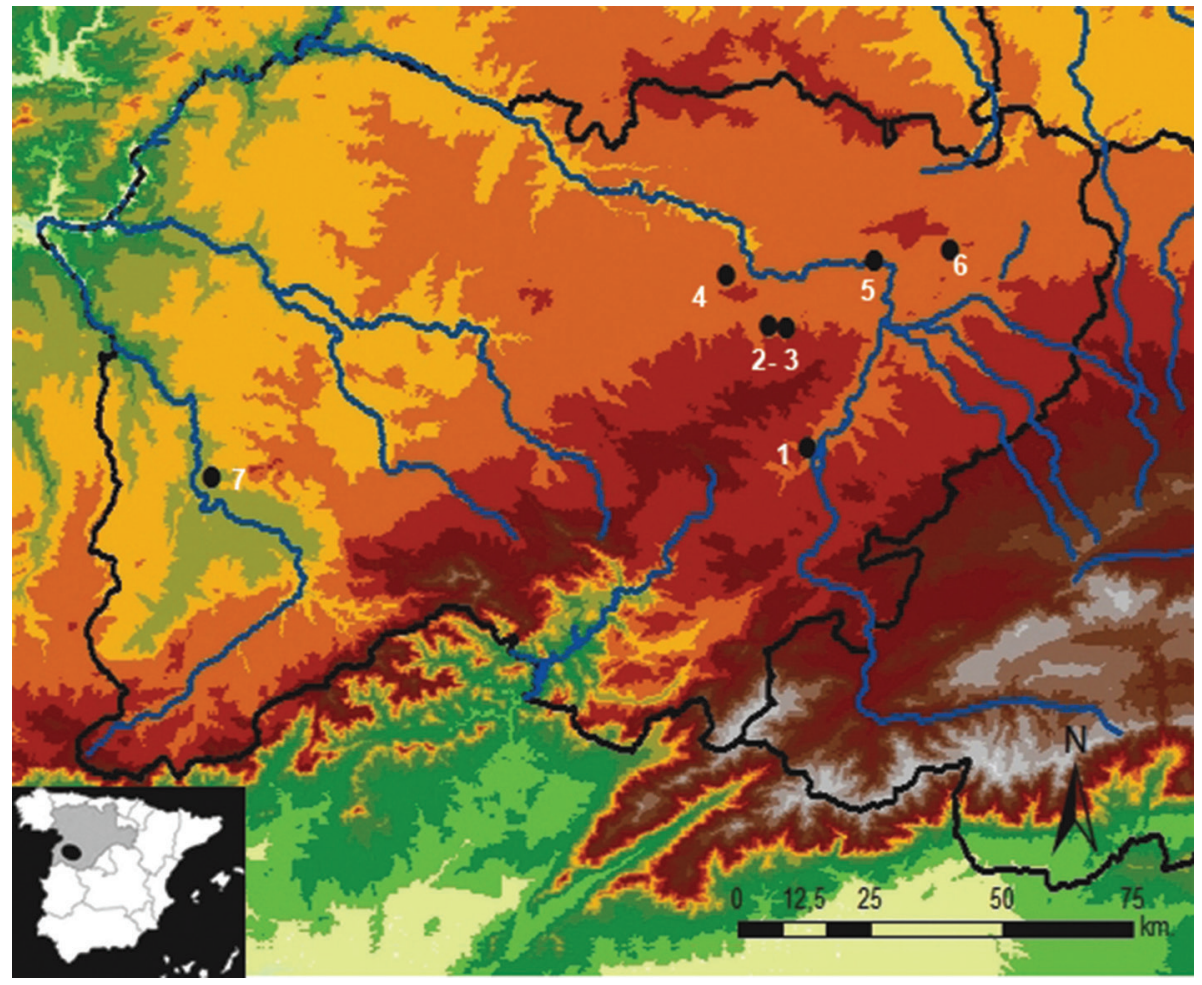

discovered in 1801 at San Julián de la Valmuza Roman's villa. The mosaic floor was published in 1832 by Cean Bermudez in "Summary of Roman Antiquities of Spain" (Cean Bermudez, 1832). In 1984-1985, the villa was partially excavated and a new pavement of opus signinum and opus tesselatum was found (Garcia, Serrano, 1996, pp. 35-38; Regueras, Pérez, 1997, pp. 17-19).

On the other bank of the River Tormes, east of the city of Salamanca, remains of mosaic pavement were found at La Aceña de la Fuente, El Cenizal (San Morales) and La Vega (Villoria and Villoruela). The first settlement has two distinct parts: a residential sector (La Aceña de la Fuente) and a necropolis in the sector where ashen spots are visible (El Cenizal) (Excar, 1991-1992). In the first of these, Luis Angoso located numerous fragments of Roman pottery, metal elements, mosaic tiles and 16 fragments of slates with textual inscriptions and numerals. In 1985, a few kilometres from this site, between the municipalities of Villoria and Villoruela, a Roman villa called La Vega was discovered. In that year, García Figerola and Angoso conducted an archaeological excavation of $12 \times 12 \mathrm{~m}$ in which were discovered three floors of opus tesselatum with a geometric decoration made up of small tesserae of different colours (white, black, red and yellow) and an important piece of a mural painting (García Figuerola, Angoso, 1986; Regeras, Pérez, 1997, pp. 51-60).

In 2015, the archaeological survey undertaken in the south of the province by Pérez de Dios led to the discovery of a new Roman settlement with a mosaic floor, located in the present municipality of Fresno Alhándiga. The subsequent archaeological excavation revealed the existence of a large settlement next to the Silver Way, where was documented part of a thermal resort with three different rooms. The first room contained a geometric mosaic floor with fish and dolphins, while the other two rooms of smaller size had opus signinum and one hypocaustum in perfect condition of preservation (Pérez, de Soto, 2017).

\section{Materials and methods}

A selection of 37 tesselatum samples from seven archaeological excavations in Salamanca (Spain) (Figure 1) have been studied in order to diagnose their origin. Tesserae have been sampled from different parts of the mosaics with the purpose of creating a colour representative sample set. However, in order to minimize the impact and considering the archaeological importance of the find, sampling has been limited to this number of samples.

Mosaic tesserae are small parallelepipeds with an irregular structure that could be made of different kind of materials such as stone, marble, glass or pottery. Samples of red, green, white, cream and blue have been selected with a rectangular prism shape and average dimensions of $1.0 \times 1.0 \times 1.5 \mathrm{~cm}$. In addition, blue and cream samples usually have conchoidal fractures. A summary description of each sample is included in Table 1. The colour of the samples was studied using the Munsell Soil Color Chart (Munsell, 1975).

These samples were characterized according to their mineralogy and chemistry. In all cases, a minimal part of the sample was taken to minimize damage to archaeological objects. The samples were labelled "LV", "AZ", "SJ", "AL", "SM", "LVE" and "SA", to indicate the location of the archaeological site, followed by an identification number. 
IANSA $2018 \quad \bullet \quad I X / 1 \quad \bullet \quad 31-42$

Table 1. Samples studied: physical characteristics.

\begin{tabular}{|c|c|c|c|}
\hline Sample & Archaeological site & Munsell color & Description of the sample \\
\hline LV2 & Los Villares & Light grey (Gley 1 7/N) & Stone \\
\hline LV3 & Los Villares & Light grey (Gley $17 / N$ ) & Stone \\
\hline LV4 & Los Villares & White $(2.5 \mathrm{Y} 8 / 1)$ & Stone \\
\hline LV5 & Los Villares & Light red (10 R 6/6) & Tegulae \\
\hline LV6 & Los Villares & Light red (2.5YR 6/4) & Stone \\
\hline AZ1 & Alquería de Azán & Light bluish grey (Gley 2 7/ 10B) & Stone \\
\hline $\mathbf{A Z 2}$ & Alquería de Azán & Very pale brown (10 YR 8/2) & Stone \\
\hline $\mathbf{A Z 3}$ & Alquería de Azán & White (7.5 YR 8/1) & Stone \\
\hline $\mathbf{A Z 4}$ & Alquería de Azán & Reddish yellow (5 YR 6/6) & Tegulae \\
\hline AZ5 & Alquería de Azán & Pink (7.5 YR 7/3) & Stone \\
\hline AZ6 & Alquería de Azán & White (10YR 8/1) & Stone \\
\hline SJ1 & San Julián de la Valmuza & Light red (2.5YR 7/6) & Tegulae \\
\hline SJ2 & San Julián de la Valmuza & Very pale brown (10 YR 7/3) & Stone \\
\hline $\mathbf{S J 3}$ & San Julián de la Valmuza & Light grey (5YR 7/1) & Stone \\
\hline SJ4 & San Julián de la Valmuza & Yellow (10 R 8/6) & Stone \\
\hline AL1 & Aldearrica & Greenish grey (Gley 2 6/10BG) & Stone \\
\hline AL2 & Aldearrica & White (10YR 8/1) & Stone \\
\hline SM1 & San Morales & White (2.5YR 8/1) & Stone \\
\hline SM2 & San Morales & Brownish yellow (10 YR 6/6) & Stone \\
\hline SM3 & San Morales & Very pale brown (10 YR 8/2) & Stone \\
\hline SM4 & San Morales & White $(2.5 Y$ $8 / 1)$ & Stone \\
\hline SM5 & San Morales & White (2.5Y 8/1) & Stone \\
\hline SM6 & San Morales & White (Gley 1 8/1) & Glass \\
\hline LVE1 & La Vega & Reddish yellow (5 YR 6/6) & Tegulae \\
\hline LVE2 & La Vega & Reddish yellow (5 YR 6/8) & Stone \\
\hline LVE3 & La Vega & Pink (5 YR 8/3) & Stone \\
\hline LVE4 & La Vega & Light bluish grey (Gley 2 7/ 10B) & Stone \\
\hline LVE5 & La Vega & Light greenish grey (Gley 8 10Y) & Stone \\
\hline LVE6 & La Vega & Very pale brown (10 YR 8/3) & Stone \\
\hline LVE7 & La Vega & White (2.5YR 8/1) & Stone \\
\hline LVE8 & La Vega & White $(2.5 \mathrm{Y} 8 / 1)$ & Stone \\
\hline LVE9 & La Vega & Pink (7.5 YR 7/4) & Stone \\
\hline SA1 & Saelices & Light grey (5YR 8/1) & Stone \\
\hline SA2 & Saelices & Very pale brown ( 10 YR $8 / 2$ & Stone \\
\hline SA3 & Saelices & White (2.5YR 8/1) & Stone \\
\hline SA4 & Saelices & White $(2.5 \mathrm{Y} 8 / 1)$ & Stone \\
\hline SA5 & Saelices & Pink (7.5 YR 7/4) & Stone \\
\hline
\end{tabular}

\subsection{Mineralogical Analysis}

$\mathrm{XRD}$ is a powerful tool in characterizing archaeological materials (Eiland, Williams, 2001). For this reason, the mineralogical compositions of the samples were determined by X-Ray diffraction (XDR) using a SIEMENS D-5000 with a $\mathrm{Cu}$ anode, operating at $30 \mathrm{~mA}$ and $40 \mathrm{kV}$, using divergence and reception slits of $2 \mathrm{~mm}$ and $0.6 \mathrm{~mm}$, respectively. Peaks were identified following the criteria proposed by Schultz (1964) and Brindley and Brown (1984). The characterization of the bulk samples was performed with the Rielveld method (Rietveld, 1969; De Ruan and Ward 2002). This method allows us to quantify the mineralogical and amorphous phases of samples that cannot be analysed by other experimental techniques (Viani et al., 1999); for this reason, this method has been used in archaeology for the characterization of ceramics (Comodi et al., 2004; Compaña et al., 2010).

The minerals identified were phyllosilicates, quartz feldspar-K, plagioclase, calcite, pyroxene, dolomite and amorphous material. 


\subsection{Chemical analysis}

Dissolution of the samples was performed as follows (García Giménez et al., 2005): a minimum amount of the sample was treated with hydrofluoric acid in an open vessel, and heated on a hot plate until dryness. This was followed by the addition of aqua regia, and heated again until dryness. The residue was dissolved with $1 \mathrm{ml}$ of concentrated hydrochloric acid and diluted with water to the mark in the Teflon volumetric flasks. Care was taken to keep contamination to a minimum. Ultrapure water was used throughout and all reagents used were of analytical grade. Chemical analyses of both major and minor elements were performed by inductively coupled plasma-mass spectrometry (ICP-MS) in a SciexElan 6000 Perkin Elmer spectrometer equipped with an AS91 autosampler. Inductively-coupled plasma spectrometry is one of the most important chemical techniques for the characterization of solid materials in recent studies and is becoming more popular in archaeological studies, as it provides information on a huge number of elements (William, 2005).

A total of 69 elements were determined: $\mathrm{Al}_{2} \mathrm{O}_{3}, \mathrm{CaO}, \mathrm{K}_{2} \mathrm{O}$, $\mathrm{Fe}_{2} \mathrm{O}_{3}, \mathrm{Na}_{2} \mathrm{O}, \mathrm{MgO}, \mathrm{MnO}_{2}$, and $\mathrm{TiO}_{2}$ as major elements; $\mathrm{Li}$, $\mathrm{Be}, \mathrm{B}, \mathrm{P}, \mathrm{Sc}, \mathrm{Ti}, \mathrm{V}, \mathrm{Cr}, \mathrm{Co}, \mathrm{Ni}, \mathrm{Cu}, \mathrm{Zn}, \mathrm{Ga}, \mathrm{Ge}, \mathrm{As}, \mathrm{Se}, \mathrm{Rb}$, $\mathrm{Sr}, \mathrm{Y}, \mathrm{Zr}, \mathrm{Nb}, \mathrm{Mo}, \mathrm{Ru}, \mathrm{Rh}, \mathrm{Pd}, \mathrm{Ag}, \mathrm{Cd}, \mathrm{In}, \mathrm{Sn}, \mathrm{Sb}, \mathrm{Te}, \mathrm{Cs}, \mathrm{Ba}$, La, Ce, Pr, Nd, Sm, Eu, Gd, Tb, Dy, Ho, Er, Tm, Yb, Lu, Hf, Ta, W, Re, Os, Ir, Pt, Au, Hg, Tl, Pb, Bi, Th and $\mathrm{U}$ as minor and trace elements. Moreover, $\mathrm{SiO}_{2}$ content was estimated. Blank samples, standard samples and duplicated samples were simultaneously performed as quality control.

\subsection{Statistical Analysis}

Several analyses were done using the following programs: SPSS 16 Programme and Origin 75E version. The first step was to study the major element concentrations of the samples using box and whisker graphics in order to interpret the distribution of data. Later, a linear discriminant analysis was used for hard classification purposes, trying to establish possible connections between groups of samples and variables. This procedure is useful for classifying the dataset into groups.

\section{Results and discussion}

Table 2 shows the mineralogical results from the samples obtained by XDR. It can be observed that there is a huge variation in the mineral composition of the samples, because the samples are from different archaeological sites from the province of Salamanca, and in this region it is possible to find sedimentary, igneous and metamorphic rocks (LucenaConde, García, 1976). However, the majority of the samples are characterized by a high content of carbonates (calcite and dolomite) and the mean value of these minerals in the samples is $88 \%$. This type of mineral can be found in the Duero Basin. As mentioned previously, this soil type can be found in the Salamanca region. Thus far, these samples must relate to a local production. In addition, traces of strontianite $\left(\mathrm{SrCO}_{3}\right)$ were detected in two samples (LV2 and LV3). Only eleven samples presented values of carbonate content below
Figure 2. Tesselatum samples. Views from binocular loupe at $32 \times$ magnification: A) SM6; B) SJ1; C) LVE4; D) SA1.

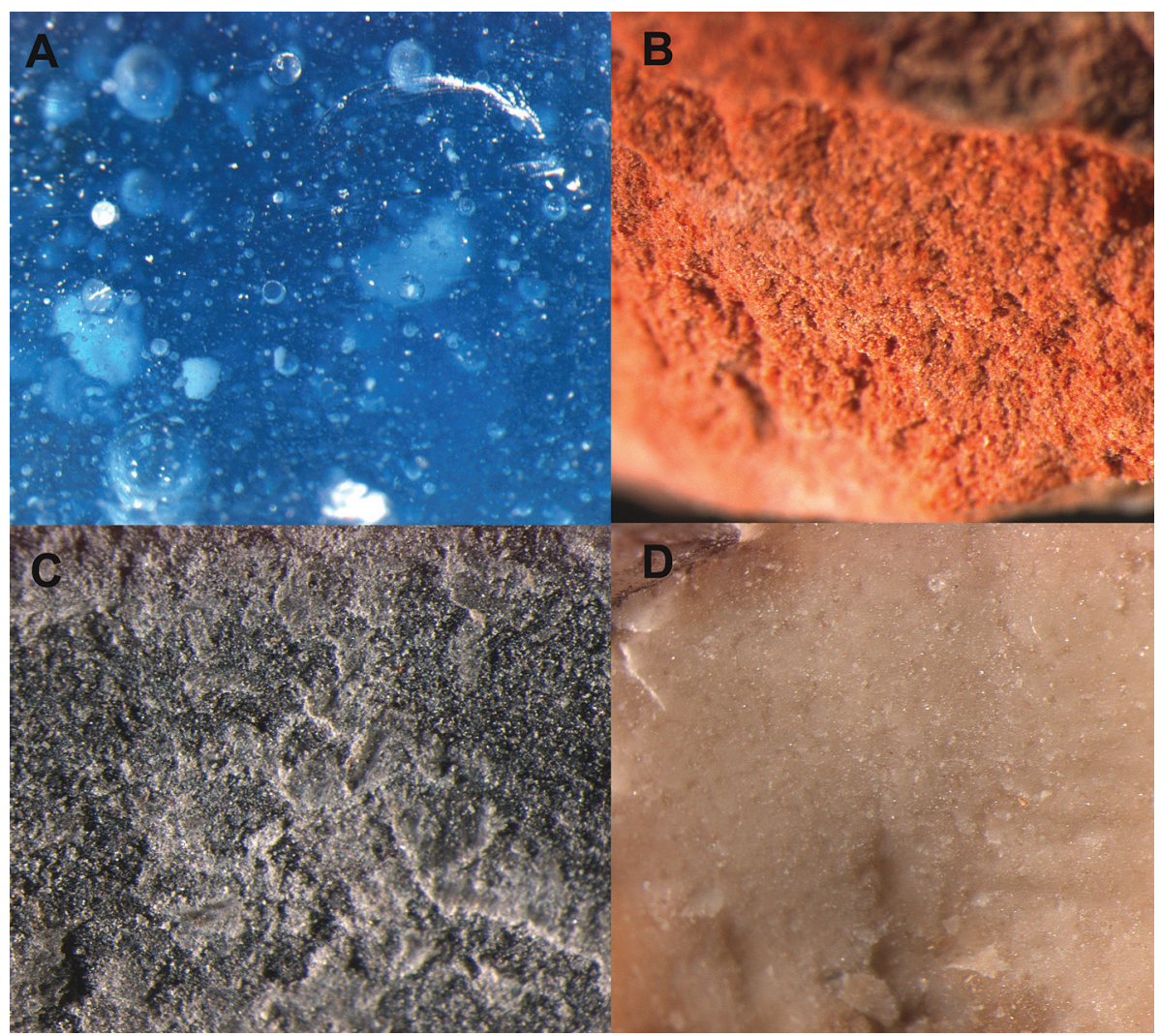


Table 2. Mineralogical composition of the samples. P - Phyllosilicate; Qtz - Quartz, FK - Potassium feldspar; FCNa - Sodium-calcium feldspar; Cal calcite; Dol - Dolomite; Kaolinite; Opal; Stronzionite; Amorphous material; R, X².

\begin{tabular}{|c|c|c|c|c|c|c|c|c|c|c|c|c|}
\hline Mineral (\%) & $\mathbf{P}$ & Qtz & FK & FCNa & Cal & Dol & Kaolinite & Opal & Stronzianite & $\begin{array}{c}\text { Amorphous } \\
\text { material }\end{array}$ & $\mathbf{R}$ & $\chi^{2}$ \\
\hline LV2 & 35 & 4 & 0 & 0 & 56 & 0 & 0 & 0 & 0.001 & 5 & 26.8 & 14.7 \\
\hline LV3 & 0.001 & 0.001 & 0 & 0 & 98 & 0 & 0 & 0 & 0.001 & 2 & 20.9 & 9.7 \\
\hline LV4 & 0.001 & 0 & 0 & 0 & 10 & 88 & 0 & 0 & 0 & 2 & 19.4 & 6.8 \\
\hline LV5 & 28 & 32 & 0 & 0 & 37 & 0 & 0 & 0 & 0 & 3 & 16.7 & 6.7 \\
\hline LV6 & 0 & 75 & 5 & 0 & 12 & 0 & 0 & 0 & 0 & 8 & 33.3 & 8.6 \\
\hline AZ1 & 15 & 6 & 0 & 2 & 6 & 69 & 0 & 0 & 0 & 2 & 20.9 & 9.7 \\
\hline AZ2 & 0 & 0 & 0 & 0 & 96 & 1 & 0 & 0 & 0 & 3 & 22.3 & 8.7 \\
\hline AZ3 & 0 & 0 & 0 & 0 & 94 & 1 & 0 & 0 & 0 & 5 & 17.3 & 7.0 \\
\hline AZ4 & 52 & 19 & 0.001 & 8 & 12 & 0 & 0 & 0 & 0 & 10 & 31.3 & 7.6 \\
\hline AZ5 & 10 & 10 & 0 & 5 & 5 & 66 & 0 & 0 & 0 & 4 & 26.0 & 4.5 \\
\hline AZ6 & 5 & 45 & 0.001 & 0.001 & 44 & 0.001 & 0 & 0 & 0 & 6 & 16.4 & 6.5 \\
\hline SJ1 & 0 & 0 & 0 & 0 & 97 & 0 & 0 & 0 & 0 & 3 & 21.1 & 5.4 \\
\hline $\mathrm{SJ} 2$ & 13 & 6 & 0 & 2 & 6 & 68 & 0 & 0 & 0 & 5 & 22.6 & 9.4 \\
\hline $\mathrm{SJ} 3$ & 0.001 & 8 & 3 & 0 & 79 & 0.001 & 0 & 0 & 0 & 10 & 18.9 & 6.9 \\
\hline SJ4 & 0 & 0 & 0 & 0 & 94 & 0 & 0 & 0 & 0 & 6 & 19.6 & 12.3 \\
\hline AL1 & 5 & 6 & 22 & 0 & 0.001 & 60 & 0 & 0 & 0 & 7 & 33.3 & 6.0 \\
\hline AL2 & 0.001 & 5 & 0 & 8 & 82 & 0.001 & 0 & 0 & 0 & 5 & 20.9 & 8.3 \\
\hline SM1 & 0 & 0.001 & 0 & 0 & 93 & 0.001 & 0 & 0 & 0 & 7 & 22.3 & 8.8 \\
\hline SM2 & 5 & 60 & 0 & 0 & 0 & 0 & 5 & 23 & 0 & 12 & 17.3 & 8.6 \\
\hline SM3 & 0 & 7 & 0 & 3 & 88 & 0.001 & 0 & 0 & 0 & 2 & 17.3 & 6.7 \\
\hline SM4 & 0 & 0 & 0 & 0 & 95 & 3 & 0 & 0 & 0 & 2 & 15.2 & 5.9 \\
\hline SM5 & 0 & 0 & 0 & 0 & 97 & 0.001 & 0 & 0 & 0 & 3 & 21.8 & 7.0 \\
\hline SM6 & vidrio & 5 & 0 & 0 & 0 & 0 & 0 & 0 & 0 & 95 & 23.2 & 10.2 \\
\hline LVE1 & 12 & 62 & 0.001 & 16 & 0.001 & 0 & 0 & 0 & 0 & 10 & 12.5 & 6.8 \\
\hline LVE2 & 10 & 39 & 24 & 5 & 10 & 0 & 0 & 0 & 0 & 12 & 17.2 & 5.4 \\
\hline LVE3 & 0 & 0 & 0 & 0 & 0.001 & 98 & 0 & 0 & 0 & 2 & 15.1 & 7.2 \\
\hline LVE4 & 0.001 & 4 & 0 & 0.001 & 82 & 10 & 0 & 0 & 0 & 4 & 12.6 & 4.3 \\
\hline LVE5 & 8 & 39 & 25 & 0.001 & 25 & 0 & 0 & 0 & 0 & 13 & 11.7 & 8.3 \\
\hline LVE6 & 8 & 50 & 0 & 0 & 7 & 0 & 0 & 19 & 0 & 16 & 17.6 & 6.4 \\
\hline LVE7 & 0 & 0 & 0 & 0 & 98 & 0.001 & 0 & 0 & 0 & 2 & 15.4 & 6.3 \\
\hline LVE8 & 0.001 & 0.001 & 0 & 0 & 97 & 0 & 0 & 0 & 0 & 3 & 16.3 & 6.9 \\
\hline LVE9 & 30 & 30 & 0 & 0 & 30 & 0 & 0 & 0 & 0 & 10 & 17.7 & 8.9 \\
\hline SA1 & 0.001 & 5 & 0 & 0 & 93 & 0.001 & 0 & 0 & 0 & 2 & 12.6 & 8.4 \\
\hline SA2 & 0.001 & 54 & 0 & 10 & 22 & 0 & 0 & 0 & 0 & 14 & 11.9 & 6.8 \\
\hline SA3 & 0 & 0 & 0 & 0 & 95 & 0.001 & 0 & 0 & 0 & 5 & 12.6 & 7.9 \\
\hline SA4 & 0 & 0 & 0 & 0 & 98 & 0.001 & 0 & 0 & 0 & 2 & 15.3 & 6.5 \\
\hline SA5 & 0.001 & 84 & 0 & 0 & 0 & 0 & 0 & 10 & 0 & 6 & 14.7 & 6.3 \\
\hline
\end{tabular}

40\% (LV5, LV6, AZ4, SM2, LVE1, LVE2, LVE5, LVE6, LVE9, SA2 and SA5) and carbonates were not detected in three of the samples (SM2, LVE1 and SA5) where the quartz content was over $70 \%$. On the other hand, the majority of the samples showed low concentrations of phyllosilicates, quartz, plagioclase and K-feldspar.
In relation to the amorphous and glass fractions, the samples were fairly homogeneous (values between 2-16\%, with a mean value of 5\%), except for sample SM6 which was made of glass ( $95 \%$ of amorphous materials, see Table 2 ).

The samples were fairly homogeneous in view of the major element concentration, due to the fact that high 
Figure 3. Box and whiskers plot of the major elements.
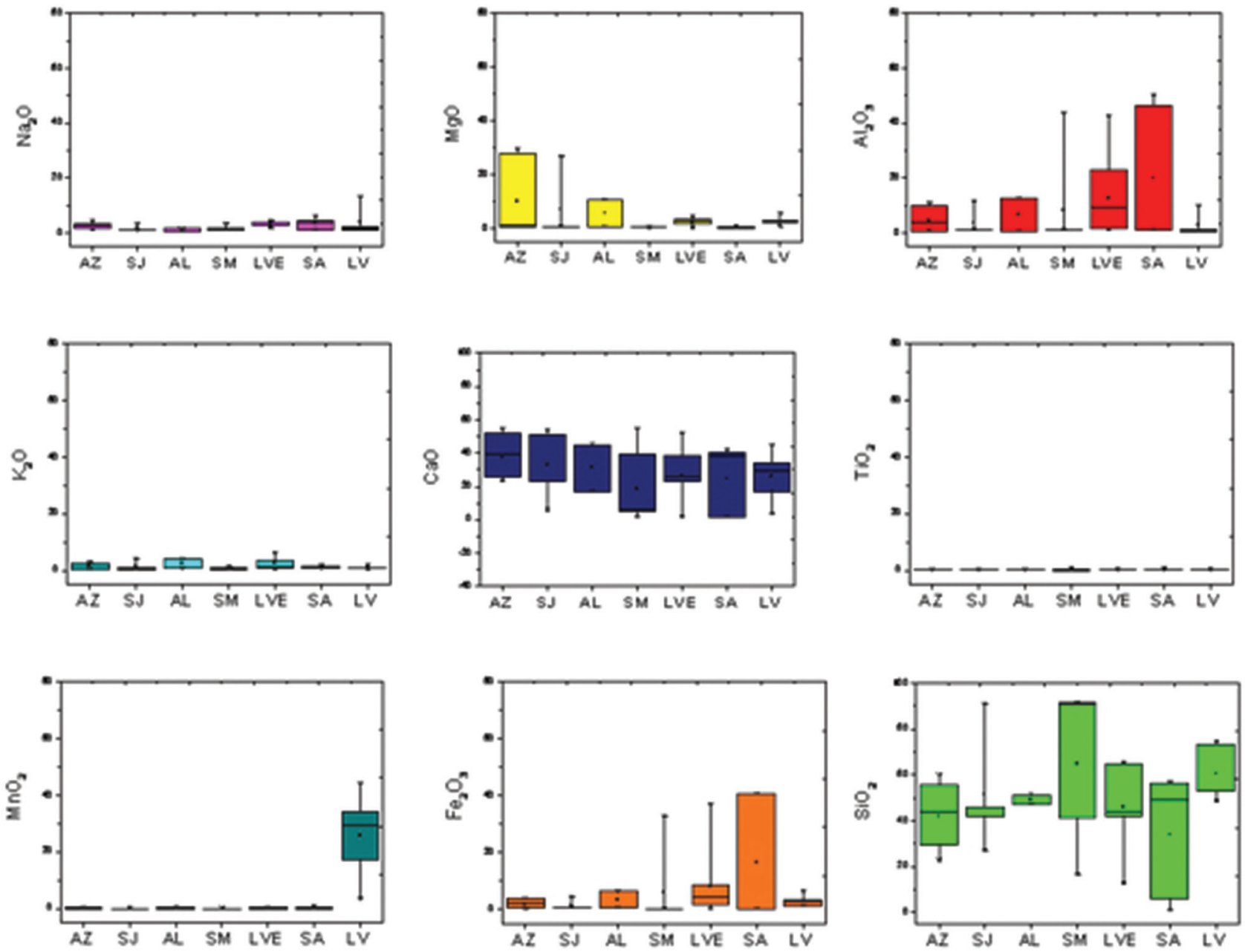

Figure 4. Box and whiskers plot of the major elements using a division according to the archaeological site. 
Table 3. Minor and trace elements concentrations (expressed in ppm).

\begin{tabular}{|c|c|c|c|c|c|c|c|c|c|c|c|c|c|c|c|c|c|c|c|c|c|c|c|c|c|c|c|c|c|c|}
\hline & $\mathbf{L i}$ & $\mathrm{Be}$ & B & $\mathbf{P}$ & $\mathrm{Sc}$ & V & $\mathrm{Cr}$ & Co & $\mathbf{N i}$ & $\mathrm{Cu}$ & $\mathrm{Zn}$ & Ga & Ge & As & $\mathrm{Se}$ & $\mathbf{R b}$ & $\mathrm{Sr}$ & $\mathbf{Y}$ & $\mathbf{Z r}$ & $\mathbf{N b}$ & Mo & $\mathbf{R u}$ & $\mathbf{R h}$ & Pd & Ag & Cd & In & Sn & Sb & $\mathrm{Te}$ \\
\hline AZ1 & 0 & 1 & 0 & 459 & 4 & 10 & 0 & 2 & 8 & 36 & 20 & 9 & 2 & 4 & 0 & 37 & 236 & 14 & 42 & 1 & 0 & 0 & 0 & 0 & 0 & 0 & 0 & 0 & 0 & 0 \\
\hline AZ2 & 0 & 0 & 15 & 512 & 1 & 0 & 0 & 1 & 0 & 22 & 5 & 1 & 0 & 0 & 0 & 12 & 133 & 3 & 27 & 0 & 0 & 0 & 0 & 0 & 0 & 1 & 0 & 0 & 0 & 0 \\
\hline AZ3 & 0 & 0 & 21 & 413 & 0 & 0 & 0 & 2 & 0 & 27 & 4 & 1 & 0 & 0 & 0 & 21 & 121 & 3 & 27 & 0 & 0 & 0 & 0 & 0 & 0 & 1 & 0 & 0 & 0 & 0 \\
\hline AZ4 & 0 & 0 & 0 & 319 & 0 & 0 & 0 & 5 & 0 & 42 & 3 & 0 & 0 & 0 & 0 & 15 & 95 & 2 & 36 & 0 & 0 & 0 & 0 & 0 & 0 & 0 & 0 & 0 & 0 & 0 \\
\hline AZ5 & 0 & 1 & 0 & 313 & 3 & 6 & 0 & 2 & 4 & 33 & 26 & 6 & 3 & 5 & 0 & 29 & 253 & 12 & 47 & 2 & 0 & 0 & م & 0 & 0 & 0 & 0 & 0 & 0 & 0 \\
\hline AZ6 & 13 & 2 & 336 & 381 & 2 & 10 & 19 & 4 & 17 & 104 & 87 & 5 & 1 & 5 & 0 & 0 & 242 & 5 & 34 & 3 & 0 & 0 & 0 & 0 & 0 & 1 & 0 & 0 & 0 & 0 \\
\hline SJ1 & 0 & 0 & 13 & 312 & 0 & 0 & 0 & 3 & 0 & 28 & 2 & 1 & 0 & 0 & 0 & 32 & 133 & 2 & 34 & 0 & 0 & 0 & 0 & 0 & 0 & 0 & 0 & 0 & 0 & 0 \\
\hline $\mathrm{SJ} 2$ & 0 & 0 & 0 & 336 & 4 & 5 & 0 & 2 & 2 & 28 & 32 & 5 & 2 & 3 & 0 & 33 & 237 & 22 & 39 & 1 & 0 & 0 & 0 & 0 & 0 & 0 & 0 & 0 & 0 & 0 \\
\hline $\mathrm{SJ} 3$ & 0 & 0 & 6 & 326 & 0 & 0 & 0 & 3 & 0 & 32 & 1 & 1 & 0 & 0 & 0 & 27 & 143 & 3 & 30 & 0 & 0 & 0 & 0 & 0 & 0 & 0 & 0 & 0 & 0 & 0 \\
\hline SJ4 & 0 & 0 & 25 & 243 & 0 & 0 & 0 & 3 & 0 & 33 & 1 & 0 & 0 & 0 & 0 & 42 & 154 & 3 & 41 & 0 & 0 & 0 & 0 & 0 & 0 & 0 & 0 & 0 & 0 & 0 \\
\hline AL1 & 12 & 2 & 0 & 1400 & 5 & 26 & 0 & 3 & 6 & 29 & 73 & 12 & 1 & 4 & 0 & 51 & 300 & 12 & 56 & 2 & 0 & 0 & 0 & 0 & 0 & 0 & 0 & 0 & 0 & 0 \\
\hline AL2 & 0 & 0 & 13 & 362 & 0 & 0 & 0 & 2 & 0 & 47 & 2 & 1 & 0 & 0 & 0 & 49 & 130 & 2 & 27 & 0 & 0 & 0 & 0 & 0 & 0 & 0 & 0 & 0 & 0 & 0 \\
\hline SM1 & 0 & 1 & 32 & 342 & 0 & 0 & 0 & 2 & 0 & 26 & 1 & 0 & 0 & 0 & 0 & 49 & 121 & 2 & 23 & 0 & 0 & 0 & 0 & 0 & 0 & 0 & 0 & 0 & 0 & 0 \\
\hline SM2 & 3 & 5 & 142 & 777 & 15 & 161 & 142 & 14 & 41 & 74 & 57 & 30 & 1 & 129 & 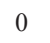 & 10 & 90 & 7 & 134 & 13 & 0 & 0 & $\sigma$ & 0 & 1 & 0 & 0 & 0 & 0 & 0 \\
\hline SM3 & 0 & 0 & 21 & 402 & 0 & 0 & 0 & 1 & 0 & 15 & 2 & 0 & 0 & 0 & 0 & 37 & 153 & 4 & 42 & 0 & 0 & 0 & 0 & 0 & 0 & 0 & 0 & 0 & 0 & 0 \\
\hline SM4 & 0 & 0 & 15 & 367 & 0 & 0 & 0 & 2 & 0 & 32 & 4 & 0 & 0 & 0 & 0 & 42 & 138 & 5 & 53 & 0 & 0 & 0 & 0 & 0 & 0 & 0 & 0 & 0 & 0 & 0 \\
\hline SM5 & 0 & 0 & 18 & 472 & 1 & 0 & 0 & 1 & 0 & 18 & 3 & 1 & 0 & 0 & 0 & 16 & 148 & 4 & 15 & 0 & 0 & 0 & 0 & 0 & 0 & 1 & 0 & 0 & 0 & 0 \\
\hline SM6 & 0 & 0 & 0 & 305 & 0 & 58 & 79 & 0 & 0 & 53 & 2 & 2 & 2 & 0 & 0 & 32 & 257 & 7 & 26 & 0 & 0 & 0 & 0 & 0 & 0 & 0 & 0 & 0 & 0 & 0 \\
\hline LVE1 & 0 & 3 & 0 & 74 & 5 & 31 & 0 & 12 & 29 & 88 & 143 & 20 & 0 & 3 & 0 & 105 & 159 & 9 & 46 & 5 & 0 & 0 & 0 & 0 & 0 & 0 & 0 & 0 & 0 & 0 \\
\hline LVE2 & 0 & 0 & 0 & 148 & 4 & 6 & 0 & 2 & 5 & 37 & 32 & 0 & 0 & 0 & 0 & 58 & 1347 & 6 & 89 & 0 & 0 & 0 & 0 & 0 & 0 & 0 & 0 & 0 & 28 & 0 \\
\hline LVE3 & 0 & 1 & 2 & 87 & 1 & 10 & 11 & 1 & 5 & 18 & 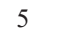 & 2 & 0 & 39 & 0 & 8 & 126 & 2 & 29 & 1 & 3 & 0 & 0 & 0 & 0 & 0 & 0 & 0 & 16 & 0 \\
\hline LVE4 & 0 & 0 & 0 & 186 & 7 & 17 & 0 & 2 & 10 & 49 & 19 & 8 & . & 1 & 0 & 44 & 1568 & 11 & 74 & 1 & 2 & 0 & 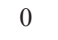 & 0 & 0 & 0 & 0 & 0 & 0 & 0 \\
\hline LVE5 & 0 & 0 & 0 & 58 & 4 & 6 & 19 & 2 & 9 & 25 & 3 & 1 & 0 & 26 & 0 & 4 & 253 & 0 & 17 & 0 & 0 & 0 & 0 & 0 & 0 & 0 & 0 & 0 & 8 & 0 \\
\hline LVE6 & 3 & 6 & 133 & 645 & 23 & 178 & 134 & 9 & 53 & 88 & 43 & 27 & 2 & 136 & 0 & 15 & 107 & 8 & 122 & 18 & 0 & 0 & 0 & 0 & 3 & 0 & 0 & 0 & 0 & 0 \\
\hline LVE7 & 0 & 0 & 34 & 402 & 2 & 0 & 0 & 2 & 0 & 32 & 2 & 3 & 0 & 0 & 0 & 26 & 132 & 7 & 21 & 0 & 0 & 0 & . & 0 & 0 & 3 & 0 & 0 & 0 & 0 \\
\hline LVE8 & 18 & 0 & 996 & 183 & 1 & 11 & 3 & 1 & 2 & 13 & 0 & 1 & 0 & 4 & 0 & 4 & 156 & 1 & 13 & 1 & 0 & 0 & 0 & 1 & 0 & 0 & 0 & 3 & 2 & 0 \\
\hline LVE9 & 44 & 2 & 469 & 317 & 6 & 73 & 52 & 5 & 28 & 33 & 43 & 14 & 1 & 32 & 0 & 29 & 295 & 9 & 85 & 5 & 2 & 0 & 0 & 0 & 0 & 0 & 0 & 6 & 4 & 0 \\
\hline SA1 & 0 & 0 & 99 & 19175 & 0 & 0 & 0 & 7 & 24 & 89 & 272 & 0 & 0 & 0 & 0 & 0 & 361 & 3 & 17 & 1 & 0 & 0 & 0 & 0 & 0 & 1 & 0 & 0 & 52 & 0 \\
\hline SA2 & 5 & 3 & 127 & 537 & 35 & 248 & 149 & 3 & 37 & 80 & 32 & 15 & 1 & 168 & 0 & 6 & 68 & 4 & 154 & 32 & 0 & 0 & 0 & 0 & 2 & 0 & 0 & 0 & 0 & 0 \\
\hline SA3 & 0 & 0 & 27 & 19932 & 0 & 0 & 0 & 0 & 0 & 27 & 0 & 0 & 0 & 0 & 0 & 38 & 167 & 4 & 19 & 0 & 0 & 0 & 0 & 0 & 0 & 8 & 0 & 0 & 0 & 0 \\
\hline SA4 & 0 & 0 & 12 & 21 & 0 & 0 & 0 & 0 & 0 & 14 & 0 & 0 & 0 & 0 & 0 & 25 & 147 & 2 & 37 & 0 & 0 & 0 & 0 & 0 & 0 & 3 & 0 & 0 & 0 & 0 \\
\hline SA5 & 3 & 3 & 145 & 632 & 35 & 142 & 121 & 13 & 61 & 54 & 32 & 52 & 3 & 160 & 0 & 17 & 121 & 6 & 142 & 32 & 0 & 0 & 0 & 0 & 4 & 0 & 0 & 0 & 0 & 0 \\
\hline LV2 & 56 & 3 & 967 & 306 & 4 & 41 & 29 & 4 & 21 & 36 & 0 & 8 & 0 & 4 & 0 & 29 & 1008 & 15 & 43 & 4 & 1 & 0 & 0 & 1 & 0 & 0 & 0 & 5 & 3 & 0 \\
\hline LV3 & 22 & 1 & 1908 & 104 & 3 & 22 & 13 & 3 & 14 & 43 & 0 & 4 & 0 & 10 & 0 & 20 & 1705 & 6 & 31 & 1 & 1 & 0 & 0 & 1 & 1 & 0 & 0 & 2 & 4 & 0 \\
\hline LV4 & 56 & 0 & 1510 & 85 & 2 & 37 & 20 & 3 & 16 & 38 & 0 & 5 & 2 & 12 & 5 & 10 & 162 & 4 & 24 & 1 & 1 & 0 & 0 & 3 & 0 & 0 & 0 & 6 & 8 & 0 \\
\hline LV5 & 52 & 3 & 969 & 419 & 5 & 66 & 44 & 9 & 36 & 36 & 0 & 16 & 1 & 20 & 0 & 28 & 589 & 10 & 50 & 8 & 1 & 0 & 0 & 2 & 0 & 0 & 0 & 7 & 4 & 0 \\
\hline LV6 & 0 & 0 & 0 & 220 & 6 & 12 & 11 & 3 & 419 & 101 & 282 & 2 & 0 & 187 & 0 & 2 & 24 & 3 & 3312 & 3 & 321 & 0 & 0 & 0 & 3 & 0 & 1 & 170 & 31 & 0 \\
\hline
\end{tabular}

variability was only found for the concentrations of $\mathrm{Ca}$ and $\mathrm{Si}$. These results can be observed with the box and whiskers graph of the major element concentrations using all the samples together (Figure 2). This representation helps interpret the distribution of data. In this plot, each box encloses the middle $50 \%$, the median being represented as a horizontal line inside the box. Vertical lines extending from each end of the box ("whiskers") enclose the data within 1.5 interquartile ranges. Values falling beyond the whiskers, but within three interquartile ranges, are plotted as individual points (suspect outliers). Further outside points (outliers) are distinguished.
A detailed study was made by representing the major element concentrations using a division according to the archaeological site (LV, AZ, SJ, AL, SM, LVE and SA) (Figure 4). It shows small variability between samples with regard to their content of $\mathrm{Na}, \mathrm{K}$, Ti and Mn (except for the content of Mn in samples from LV). By contrast, there was high variability in the contents of $\mathrm{Si}$ and $\mathrm{Ca}$ for all samples in all the archaeological sites as was demonstrated in the Figure 2. Concentration of $\mathrm{Mg}$ showed high variability in the samples from $\mathrm{AZ}$ and $\mathrm{AL}$ and small variability in the rest of the samples. In the case of Al, samples from AZ, AL, LVE and SA showed high Al content variability and small variability for samples from SJ, SM and LV. Finally, 
Table 4. Minor and trace elements concentrations (expressed in ppm).

\begin{tabular}{|c|c|c|c|c|c|c|c|c|c|c|c|c|c|c|c|c|c|c|c|c|c|c|c|c|c|c|c|c|c|c|}
\hline & Cs & $\mathbf{B a}$ & La & $\mathrm{Ce}$ & Pr & Nd & Sm & $\mathbf{E u}$ & Gd & $\mathbf{T b}$ & Dy & Ho & $\mathbf{E r}$ & $\mathbf{T m}$ & $\mathbf{Y b}$ & $\mathbf{L u}$ & Hf & $\mathbf{T a}$ & $\mathbf{W}$ & $\mathbf{R e}$ & Os & $\mathbf{I r}$ & $\mathbf{P t}$ & $\mathbf{A u}$ & $\mathbf{H g}$ & Tl & $\mathbf{P b}$ & $\mathbf{B i}$ & Th & $\mathbf{U}$ \\
\hline $\mathrm{AZ} 1$ & 2 & 361 & 18 & 33 & 5 & 14 & 3 & 1 & 3 & 0 & 2 & 1 & 2 & 0 & 1 & 0 & 1 & 0 & 1 & 0 & 0 & 0 & 0 & 0 & 0 & 0 & 7 & 0 & 8 & 2 \\
\hline AZ2 & 1 & 202 & 2 & 3 & 0 & 1 & 0 & 0 & 0 & 0 & 0 & 0 & 0 & 0 & 0 & 0 & 0 & 0 & 1 & 0 & 0 & 0 & 0 & 0 & 0 & 0 & 2 & 0 & 1 & 0 \\
\hline AZ3 & 1 & 309 & 2 & 1 & 0 & 1 & 0 & 0 & 0 & 0 & 0 & 0 & 0 & 0 & 0 & 0 & 0 & 0 & 1 & 0 & 0 & 0 & 0 & 0 & 0 & 0 & 1 & 0 & 1 & 0 \\
\hline AZ4 & 3 & 257 & 6 & 0 & 0 & 0 & 0 & 0 & 0 & 0 & 0 & 0 & 0 & 0 & 0 & 0 & 0 & 0 & 2 & 0 & 0 & 0 & 0 & 0 & 0 & 0 & 1 & 0 & 1 & 0 \\
\hline AZ5 & 2 & 347 & 22 & 37 & 6 & 12 & 6 & 2 & 4 & 0 & 3 & 2 & 1 & 0 & 1 & 0 & 1 & 0 & 1 & 0 & 0 & 0 & 0 & 0 & 0 & 0 & 5 & 0 & 3 & 2 \\
\hline AZ6 & 0 & 317 & 6 & 11 & 2 & 5 & 1 & 0 & 1 & 0 & 1 & 0 & 0 & 0 & 0 & 0 & 1 & 0 & 3 & 0 & 0 & 0 & 0 & 0 & 0 & 0 & 0 & 1 & 44 & 1 \\
\hline SJ1 & 0 & 257 & 3 & 0 & 0 & 0 & 0 & 0 & 0 & 0 & 0 & 0 & 0 & 0 & 0 & 0 & 0 & 0 & 1 & 0 & 0 & 0 & 0 & 0 & 0 & 0 & 1 & 0 & 1 & . \\
\hline $\mathrm{SJ} 2$ & 6 & 298 & 36 & 42 & 3 & 17 & 4 & 1 & 7 & 0 & 2 & 3 & 1 & 0 & 1 & 0 & 1 & 0 & 1 & 0 & 0 & 0 & 0 & 0 & 0 & 0 & 4 & 0 & 3 & 2 \\
\hline $\mathrm{SJ} 3$ & 0 & 275 & 2 & 0 & 0 & 0 & 0 & 0 & 0 & 0 & 0 & 0 & 0 & 0 & 0 & 0 & 0 & 0 & 2 & 0 & 0 & 0 & 0 & 0 & 0 & 0 & 2 & 0 & 1 & 0 \\
\hline SJ4 & 0 & 257 & 3 & 0 & 0 & 0 & 0 & 0 & 0 & 0 & 0 & 0 & 0 & 0 & 0 & 0 & 0 & 0 & 1 & 0 & 0 & 0 & 0 & 0 & 0 & 0 & 1 & 0 & 1 & 0 \\
\hline AL1 & 2 & 258 & 16 & 30 & 4 & 14 & 3 & 1 & 3 & 0 & 2 & 0 & 1 & 0 & 1 & 0 & 1 & 0 & 2 & 0 & 0 & 0 & 0 & 0 & 0 & 0 & 11 & 0 & 6 & 2 \\
\hline AL2 & 0 & 253 & 4 & 0 & 0 & 0 & 0 & 0 & 0 & 0 & 0 & 0 & 0 & 0 & 0 & 0 & 0 & 0 & 1 & 0 & 0 & 0 & 0 & 0 & 0 & 0 & 2 & 0 & 1 & 0 \\
\hline SM1 & 0 & 169 & 2 & 0 & 0 & 0 & 0 & 0 & 0 & 0 & 0 & 0 & 0 & 0 & 0 & 0 & 0 & 0 & 1 & 0 & 0 & 0 & 0 & 0 & 0 & 0 & 3 & 0 & 5 & 0 \\
\hline SM2 & 1 & 291 & 5 & 9 & 1 & 5 & 1 & 0 & 1 & 0 & 1 & 0 & 1 & 0 & 1 & 0 & 3 & 2 & 70 & 0 & 0 & 0 & 0 & 0 & 0 & 0 & 11 & 0 & 25 & 4 \\
\hline SM3 & 0 & 133 & 1 & 0 & 0 & 0 & 0 & 0 & 0 & 0 & 0 & 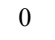 & 0 & 0 & 0 & 0 & 0 & 0 & 1 & 0 & 0 & 0 & 0 & 0 & 0 & 0 & 2 & 0 & 7 & 0 \\
\hline SM4 & 0 & 237 & 2 & 0 & 0 & 0 & 0 & 0 & 0 & 0 & 0 & 0 & 0 & 0 & 0 & 0 & 0 & 0 & 4 & 0 & 0 & 0 & 0 & 0 & 0 & 0 & 3 & 0 & 5 & 0 \\
\hline SM5 & 1 & 133 & 2 & 3 & 0 & 1 & 0 & 0 & 0 & 0 & 0 & 0 & 0 & 0 & 0 & 0 & 0 & 0 & 1 & 0 & 0 & 0 & 0 & 0 & 0 & 0 & 2 & 0 & 1 & 0 \\
\hline SM6 & 8 & 216 & 6 & 8 & 0 & 0 & 0 & 0 & 0 & 0 & 0 & 0 & 0 & 0 & 0 & 0 & 0 & 0 & 0 & 0 & 0 & 0 & 0 & 0 & 0 & 3 & 2 & 0 & 0 & 0 \\
\hline LVE1 & 6 & 570 & 25 & 56 & 7 & 24 & 5 & 1 & 4 & 0 & 2 & 0 & 1 & 0 & 1 & 0 & 1 & 1 & 3 & 0 & 0 & 0 & 0 & 0 & 0 & 0 & 10 & 0 & 8 & 2 \\
\hline LVE2 & 0 & 257 & 7 & 37 & 9 & 3 & 0 & 0 & 0 & 0 & 0 & 3 & 2 & 0 & 0 & 0 & 3 & 0 & 1 & 0 & 0 & 0 & 0 & 0 & 0 & 0 & 10 & 0 & 0 & 0 \\
\hline LVE3 & 0 & 464 & 3 & 4 & 1 & 2 & 0 & 0 & 0 & 0 & 0 & 0 & 0 & 0 & 0 & 0 & 1 & 0 & 1 & 0 & 0 & 0 & 0 & 0 & 0 & 0 & 16 & 0 & 1 & 0 \\
\hline LVE4 & 2 & 224 & 16 & 31 & 12 & 2 & 1 & 2 & 0 & 2 & 2 & 0 & 1 & 0 & 1 & 0 & 2 & 0 & 2 & 0 & 0 & 0 & 0 & 0 & 0 & 0 & 8 & 0 & 5 & 1 \\
\hline LVE5 & 0 & 375 & 2 & 8 & 0 & 0 & 0 & 0 & 0 & 0 & 0 & 0 & 0 & 0 & 0 & 0 & 0 & 0 & 0 & 0 & 0 & 0 & 0 & 0 & 0 & 0 & 9 & 0 & 0 & 0 \\
\hline LVE6 & 5 & 199 & 4 & 12 & 2 & 3 & 2 & 0 & 2 & 0 & 4 & 0 & 2 & 0 & 2 & 0 & 3 & 1 & 26 & 0 & 0 & 0 & 0 & 0 & 0 & 0 & 7 & 0 & 13 & 5 \\
\hline LVE7 & 4 & 173 & 6 & 15 & 0 & 2 & 0 & 0 & 0 & 0 & 0 & 0 & 0 & 0 & 0 & 0 & 0 & 0 & 4 & 0 & 0 & 0 & 0 & 0 & 0 & 0 & 4 & 0 & 4 & 0 \\
\hline LVE8 & 0 & 72 & 1 & 2 & 0 & 1 & 0 & 0 & 0 & 0 & 0 & 0 & 0 & 0 & 0 & 0 & 0 & 0 & 147 & 0 & 0 & 0 & 0 & 0 & 0 & 0 & 6 & 0 & 1 & 1 \\
\hline LVE9 & 1 & 288 & 14 & 30 & 3 & 13 & 2 & 1 & 2 & 0 & 2 & 0 & 1 & 0 & 1 & 0 & 2 & 1 & 303 & 0 & 0 & 0 & 0 & 0 & 0 & 0 & 48 & 0 & 6 & 2 \\
\hline SA1 & 0 & 333 & 3 & 2 & 1 & 2 & 0 & 0 & 0 & 0 & 0 & 0 & 0 & 0 & 0 & 0 & 1 & 0 & 5 & 0 & 0 & 0 & 0 & 0 & 0 & 0 & 21 & 0 & 0 & 8 \\
\hline SA2 & 0 & 352 & 2 & 21 & 1 & 2 & 1 & 0 & 0 & 0 & 4 & 0 & 0 & 0 & 1 & 0 & 2 & 1 & 15 & 0 & 0 & 0 & 0 & 0 & 0 & 0 & 3 & 0 & 5 & 6 \\
\hline SA3 & 2 & 146 & 3 & 12 & 0 & 1 & 0 & 0 & 0 & 0 & 0 & 0 & 0 & 0 & 0 & 0 & 0 & 0 & 9 & 0 & 0 & 0 & 0 & 0 & 0 & 0 & 13 & 0 & 2 & 0 \\
\hline SA4 & 1 & 133 & 2 & 7 & 0 & 1 & 0 & 0 & 0 & 0 & 0 & 0 & 0 & 0 & 0 & 0 & 0 & 0 & 3 & 0 & 0 & 0 & 0 & 0 & 0 & 0 & 7 & 0 & 1 & 0 \\
\hline SA5 & 3 & 225 & 5 & 17 & 4 & 2 & 6 & 0 & 3 & 0 & 3 & 0 & 4 & 0 & 1 & 0 & 3 & 1 & 32 & 0 & 0 & 0 & 0 & 0 & 0 & 0 & 4 & 0 & 20 & 2 \\
\hline LV2 & 1 & 156 & 13 & 26 & 3 & 10 & 2 & 1 & 2 & 0 & 2 & 1 & 1 & 0 & 1 & 0 & 1 & 1 & 333 & 0 & 0 & 0 & 0 & 0 & 0 & 0 & 26 & 2 & 4 & 1 \\
\hline LV3 & 1 & 93 & 6 & 12 & 1 & 5 & 1 & 0 & 1 & 0 & 1 & 0 & 1 & 0 & 0 & 0 & 1 & 0 & 278 & 0 & 0 & 0 & 1 & 0 & 0 & 0 & 27 & 1 & 2 & 1 \\
\hline LV4 & 0 & 84 & 5 & 10 & 1 & 4 & 1 & 0 & 1 & 0 & 1 & 0 & 0 & 0 & 0 & 0 & 0 & 0 & 890 & 0 & 0 & 0 & 3 & 0 & 0 & 0 & 7 & 1 & 2 & 1 \\
\hline LV5 & 1 & 603 & 16 & 32 & 4 & 15 & 3 & 1 & 2 & 0 & 0 & 1 & 1 & 0 & 1 & 0 & 1 & 1 & 312 & 0 & 0 & 0 & 0 & 0 & 0 & 0 & 37 & 0 & 6 & 2 \\
\hline LV6 & 0 & 124 & 3 & 6 & 1 & 3 & 1 & 0 & 1 & 0 & 1 & 0 & 0 & 0 & 0 & 0 & 10 & 0 & 1 & 0 & 0 & 0 & 0 & 1 & 5 & 0 & 2667 & 0 & 2 & 2 \\
\hline
\end{tabular}

high and medium variability in the content of Fe was obtained in the samples of SA, AZ, AL and LVE and small variability in the rest of the samples (Figure 4).

In the Tables 3 and 4 the values of the concentrations of the minor elements are represented. It is very significant that there are values $>1000 \mathrm{ppm}$ of $\mathrm{Sr}$ in four of the samples (LV2, LV3, LVE4 and LVE2), this fact being related to the presence of stronzianite which was detected by the XRD in LV2 and LV3. Another important fact is that high values of W $(>100$ ppm) were obtained in samples LV2, LV3, LV4, LV5, LVE8 and LVE9. This fact is related to a special geological feature of Salamanca Province, where there are some granitic rocks containing mineralizations of high concentrations of $\mathrm{W}$ and this element was extracted from some mines in the region (Antona et al., 1990; Burkhardt et al., 1987; Pellitero et al., 1976; Llorens, 2011). Therefore, these samples were clearly manufactured in the Salamanca region.

The supply of materials in the Duero basin contrasts with the samples analysed in the city of Ávila or the Roman village of La Olmeda (Palencia). In Ávila, red tesserae were found to have come from the Almaden area (Soto et al., 2014), and in the luxurious village of La Olmeda tesserae came from the Cantabrian mountains, localized between Alar del Rey and Aguilar de Campoo (Regueras 2013, p. 178). 


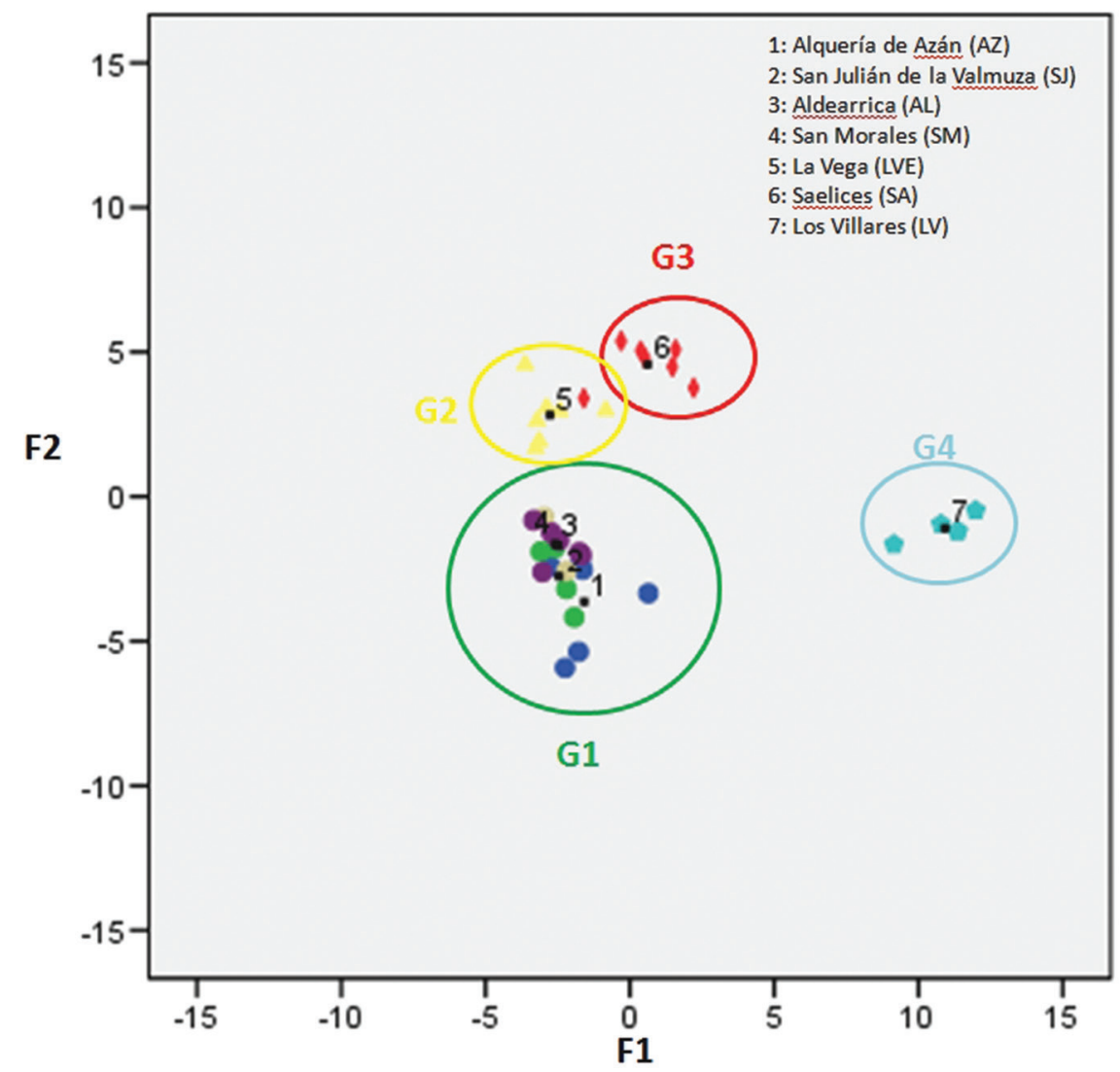

Figure 5. Graphical representation of the samples as a function of two canonical discriminant functions. 1 - Alquería de Azán (AZ); 2 - San Julián de la Valmuza (SJ); 3 - Aldearrica (AL); 4 - San Morales (SM); 5 - La Vega (LVE); 6 - Saelices (SA) and 7 - Los Villares (LV).
To study the minor concentration of the samples in detail, a linear discriminant analysis using SPSS was used for trying to establish possible connections between groups of samples and variables. The samples were divided into seven groups depending on their archaeological site: LV, AZ, SJ, AL, SM, LVE and SA. This analysis was used for the difficulty of classification in trying to establish possible connections between groups of samples and variables and possible connections among the ceramic samples. This procedure is useful for classifying the dataset into groups. It generates a small number of functions of quantitative measurements, which are linear combinations of the standardized pattern variables with weight coefficients. The procedure assumes that the variables are drawn from a population with multivariate normal distributions and that variables have equal variances. Figure 5 shows that there are four groups. The first, G1, included all the samples from AZ, SJ, AL and SM archaeological sites that are characterized by their content of As, Zn, Sc, V, Ni and Co. G2 is represented by the samples from LVE and one sample from SA, characterized by their content of As, Zn, Sc, Cr and U. G3 contained only the samples of the SA archaeological site (concentrations of $\mathrm{Ni}, \mathrm{Nb}, \mathrm{Ce}, \mathrm{Cr}$, As and U). Finally, G4 is the group of samples from LV by their concentration of As, Zn, Sc, V, Ni and Co.

This means that even though there were seven archaeological sites with mosaics in Salamanca, there were only four areas of production of these materials. In addition, these results show that in the archaeological sites closest to the city of Salamanca, i.e. AZ, SJ, AL and SM, the same material was used for the production of the mosaics and samples could be shared between these archaeological sites.

\section{Conclusions}

Archaeometric techniques allow the characterization of the materials used in the manufacture of mosaics. The results of this type of analysis let the commercial relations between quarries to be established, it being possible to observe great movements of materials that were coming from remote areas (Álvarez et al., 1985; Arana, Ramallo, 1986).

In our analysis we have been able to detect great variation in the materials used for the production of the locally found tesserae (stones, ceramics or glass). These very different materials must respond mainly to two demands: the colour requirement and the availability of raw materials. However, $88 \%$ of the samples come from the Duero basin, so the use of easily available materials is evident. The vast majority of the stone samples are limestone, something that could be linked to the ease of carving in lieu of the other stones of the area that were more difficult to work with. In addition, another advantage of the limestone is its wide chromatic variety. Only one of the samples was of dark blue-black glass (SM6). This sample presents a composition of calcium silicate, a typical composition found in Roman glass (Palomar, 2011, p. 59). However, the comparison of our results with other studies on glass tiles shows that there is not a great divergence in their 
production, but rather a standardization, as it corresponds to the vitreous production in the Roman age (Ricciardi et al., 2009, p. 2558).

Through this study we have been able to determine that the majority of the samples analysed come from the province of Salamanca. Based on the results obtained we have documented four different groups. Group 1, to which belong the two archaeological sites of Miranda de Azán AZ and AL), San Julián de la Valmuza (SJ) and Aceña de la Fuente (part of SM) can most likely be explained by their geographical proximity. The very same mosaic workshop would work for these four archaeological sites, or at least the workshop would get its raw materials from the same place. Group 2 is more complicated to analyse since it has a similar sample to those documented in Group 3, i.e. the group furthest away from all the others. However, we are talking about the same geographic context articulated by the Silver Way, so it would not be so complicated for them to be an exchange of building materials within sites in Group 2. The remaining two groups (groups 3 and 4), despite being located in areas that are relatively geographically close, have used different materials. The existence of these welldifferentiated groups has led us to conclude the existence of at least four workshops in the province of Salamanca, since in the case of tesserae tiles of the same colours, not all of them relate to the same areas of provenance.

\section{Acknowledgements}

We would like to glad to Alberto Bescós, Director of the Salamanca Museum, for his kindness and willingness to provide us with samples for the study, as well as Julio Sánchez-Tabernero and Paco Boyero, for allowing us to work on their property. We would also like to thank to the Junta de Castilla y León for the economic support for the archaeological excavation in Los Villares (Salamanca).

\section{References}

ÁlVAREZ, A., BRU, E., PLANA, F., 1985. Identificación de materiales lapídeos arqueológicos mediante difracción y fluorescencia de rayos X. Boletín de la Sociedad Española de Mineralogía, 8, 399-406.

ANTONA, J.F., BURKHARDT, R., GARCÍA SÁNCHEZ, A., 1990. Distribución geoquímica de $\mathrm{Au}$ en granitos con mineralizaciones filonianas de As, W y Au. NW de Salamanca. Cuaderno La. Xeolóxico de Laxe, 15, 17-24.

ARANA, R., RAMALLO, S., 1986. Mineralogía y petrología de materiales arqueológicos de época romana en la región murciana. Comité mixto Universidad de Murcia-Caja de Ahorros Provincial.

ARIÑO, E., DÍAZ, P., 1999. La economía agraria de la Hispania romana: colonización y territorio. Studia histórica, Historia Antigua, 17, 153-192.

BENET, N., SANTONJA, M., 1990. Arqueología preventiva y de Gestión (1984-1988). Salamanca. Nvmantia, 3, 281-293.

BERTELLI, C., 1988. Ilmosaico. Milan: Mondadori Electa.

BRINDLEY, G. W. and BROWN, G., 1984. Crystal Structures of Clay Minerals and Their X-Ray Identification. London: Mineralogical Society Monograph.

BURKHARDT, R., GARCÍA SÁNCHEZ, A., GRACIA PLAZA, A. S., 1987. Mineralizaciones (Sn, W, Au) y control estructural en el Oeste de
Salamanca y Zamora. Cuaderno La. Xeolóxico de Laxe, 12, 289-301.

CEÁN BERMÚDEZ, J. A., 1832. Sumario de las antigüedades romanas que hay en España, en especial las pertenecientes a las Bellas Artes. Madrid: Imprenta de Miguel de Burgos.

CHAVARRIA, A., 2006. Villas en Hispania durante la Antigüedad tardía. In: A. Chavarria, J. Arce, G. P. Brogiolo, eds. Villas tardoantiguas en el Mediterráno Occidental. CSIC. Anejos de Archivo Español de Arqueología 49, Madrid, pp. 17-35.

COMODI, P. BERNARDI, M. BENTIVOGLIO M., GATTAG. D. ZANAZZI. P.F., 2004. The production and technology of glazed ceramics from the middle ages, found in the saepinum territory (Italy): a multimethodic approach. Archaeometry Volume 46, 405-419.

COMPAÑA, J. M., LEÓN REINA, L., ARANDA, M. A. G., 2010. Archaeometric characterization of Terra Sigillata Hispanica from Granada workshops. Boletín de la sociedad española de cerámica y vidrio, 49(2), 113-119.

EILAND, M. L., and WILLIAMS, Q., 2001. Investigation of Islamic Ceramics from Tell Tuneinir Using X-Ray Diffraction. Geoarchaeology: An International Journal, 8(6), 875-903.

EXCAR, 1991-1992. Prospecciones arqueológica en ocho términos municipales de la provincia de Salamanca: Aldealengua, Aldearrubia, Cabeza de Framontanos, Fuenterroble de Salvatierra, Huerta, San Morales, Valsalabroso y Villar de Peralonso. Excavation report. Deposited: Museum of Salamanca, Salamanca.

FIORENTINI, R. I., FIORENTINI, E., 2001. Mosaico. Materiali, tecniche e historia. Rávena: MWEV.

GARCÍA FIGUEROLA, M., ANGOSO, L., 1986. Informe de la excavación de la villa romana de "La Vega" (Villoria-Villoruela, Salamanca). Excavation report. Deposited: Museum of Salamanca, Salamanca.

GARCÍA GIMÉNEZ, R., VIGIL DE LA VILLA, R., RECIO DE LA ROSA, P., PETIT DOMINGUEZ, M. D., and RUCANDIO, M. I., 2005. Analytical and multivariate study of Roman age architectural terracotta from Northeast of Spain. Talanta, 65, 861-868.

GARCÍA MORALES, M., SERRANO PIEDECASAS, L., 1996. La villa romana de San Julián de la Valmuza. Excavaciones de 1984 y 1985. Madrid: Junta de Castilla y León.

INSTITUTO DE ORIENTACIÓN Y ASISTENCIA TÉCNICA DEL OESTE, 1964. Los suelos de la provincia de Salamanca. Salamanca: Instituto de Orientación y Asistencia Técnica del Oeste. Diputación Provincial de Salamanca.

JAMES, L., 2006. Byzantine glass mosaic tesserae: some materials considerations. Byzantine and Modern Greek Studies, 30, 29-47.

LLORENS, T., 2011. Las mineralizaciones Magmático-Hidrotermales de Sn-W-(Nb-Ta) del distrito de Navasfrías (SO de Salamanca). Macla, 14 , $66-68$.

LUCENA- CONDE, F., GARCÍA, A., 1976. El medio edáfico de la provincia de Salamanca. Agrochimica, 20 (4-5), 348-358.

MALUQUER DE MONTES, J., 1956. Carta Arqueológica de España. Salamanca. Diputación Provincial de Salamanca. Servicio de Investigaciones Arqueológicas. Salamanca: Servicio de Investigaciones Arqueológicas.

MARTÍN CHAMOSO, C., HERNÁNDEZ HERNÁNDEZ, A. B., 1997. Informe técnico de la excavación arqueológica de la villa romana de Sahelices el Chico, Salamanca. Excavation report. Deposited: Museum of Salamanca, Salamanca.

MARTÍN CHAMOSO, C., 2007. Memoria técnica de la excavación. Villa romana de Saelices el Chico. Excavation report. Deposited: Museum of Salamanca, Salamanca.

MARTIN VALLS, R., BENET, N., MACARRO, C., 1991. Arqueología de Salamanca. In: M. Santonja, ed. Del Paleolítico a la Historia. Salamanca: Europa Artes Gráficas, 137-163.

MENÉNDEZ BUEYES, L. R., 2000-2001. El puente romano de Salamanca y su contexto histórico. Memorias de Historia Antigua, 21-22, 149-183.

MORÁN, C., 2000. Reseña histórico artística de la provincia de Salamanca. Salamanca: Diputación provincial de Salamanca.

MUNSELL, A. H., 1975. Munsell Soil Color Chart. Baltimore: Macbeth division of Kollmorgen Corporation.

PALOMAR, T., 2011. Estudio arqueométrico de muestras procedentes de mosaicos romanos de Itálica y Carmona (Sevilla). Estrat Crític, 5, 53-60. PELLITERO, E., SAAVEDRA, J., GARCÍA SÁNCHEZ, A., ARRIBAS, A., 1976. Geoquímica del $\mathrm{W}$ en el área circundante al yacimiento de 
scheelita de Barruecopardo (Salamanca). Acta geológica Hispánica 11(5), 133-136.

PÉREZ DE DIOS, V., 2014. El poblamiento romano y tardoantiguo en el Sureste de la provincia de Salamanca. Unpublished thesis (MA). Library of UNED, Madrid.

PÉREZ DE DIOS, V., DE SOTO GARCÍA, M. R., 2017. Los Villares (Fresno Alhándiga, Salamanca): un complejo termal junto a la Vía de la Plata. Munibe, 68.

RICCI, C., BORGIA, I., BRUNETTI, B. G., SGAMELLOTTI, A., FABBRI, B., BURLA, M. C., POLIDORI, G., 2005. A study on late medieval transparent-glazed poterry and archaic majolica from Orvieto (Central Italy). Archaeometry, 47(3), 557-570.

REGUERAS, F., PÉREZ OLMEDO, E., 1997. Mosaicos romanos de la Provincia de Salamanca. Salamanca: Junta de Castilla y León.

RICCIARDI, P., COLOMBAN, P., TOURNIÉ, A., MACCHIAROLA, M., AYED, N., 2009. A non-invasive study of Roman Age mosaic glass tesserae by means of Raman spectroscopy. Journal of Archaeological Science 36, 2551-2559.

RIETVELD, H.M., 1969. A profile refinement method for nuclear andmagnetic structures. Journal of Applied Crystallography, 2, 65-71.

ROLDÁN, J. M., 1971. Iter ad Emerita Asturicam. El camino de la Plata. Salamanca, Universidad de Salamanca.

ROSSI, F., 1971. El mosaico. Pintura de piedra. Madrid: Ediciones Daimon. RUAN, C.-D., WARD, C. R., 2002. Quantitative X-ray powder diffraction analysis of clay minerals in Australian coalsusing Rietveld methods.
Applied Clay Science, 21, 227-240.

SALINAS, M., ed., 1998. Historia de Salamanca I. Prehistoria y Edad Antigua. Salamanca: Centro de Estudios Salamantinos.

SCHULTZ, L., 1964. Quantitative Interpretation of Mineralogical Composition from X- Ray and Chemical Data for Pierce Shale. Washington: Geological Survey professional paper.

DE SOTO GARCÍA, Ma . R., 2015. El Valle del Río Almar entre la II Edad del Hierro y la Alta Edad Media. Estudio de un microespacio en la Meseta Norte. Unpublished Thesis (PhD), Faculty of Geography and History, University of Salamanca.

DE SOTO GARCÍA, Ma . R., PETIT DOMÍNGUEZ, M. D., DE SOTO GARCÍA, I., GARCÍA GIMÉNEZ, R., RUCANDIO, I., 2014 Caracterización de opus tesselatum procedentes de Ávila, España. Cuadernos de Prehistoria y Arqueología, 40, 137-147.

VIANI, A., GUALTIERI, A. F., MAZZUCATO, E., VENTURELLI, P., 1999. Analisi mineralogica quantitativa con il metodo Rietveld. Applicazioni a problematiche di interesse per l'industria ceramica. Ceramurgia 29(3), 169-178.

WILLIAMS, D. F., 2005. An integrated archaeometric approach to ceramic fabric recognition. A study case on Late Roman amphora 1 from the Eastern Mediterranean. In: J. M. Gurt, J. Buxeda and M. A Cau, eds. Late Roman Coarse Wares, Cooking wares and amphorae in the Mediterranean Archaeology and Archaeometry. Oxford: BAR International Series, 613-624. 